Bidik: Jurnal Pengabdian kepada Masyarakat |Vol. 2 No. 1 Oktober 2021

Doi: https://doi.org/10.31849/bidik.v2i1.8089

\title{
Pelatihan Literasi Digital Pembelajaran Jarak Jauh Untuk Seluruh Guru SD Negeri Sumbersekar, Dau, Malang
}

\author{
Muchammad Irfan Fanani*, Mia Yuliantari, M Annas Dwi Cahyono, \\ Uwais Al Kori, Moh.Safii \\ Prodi Ilmu Perpustakaan, Fakultas Sastra, Universitas Negeri Malang \\ *Email: moh.safii@um.ac.id
}

\begin{abstract}
In the current pandemic, learning is done online, but many teachers bave not been able to maximize online learning media. This service is aimed at teachers of public elementary schools in Sumbersekar, Dau, Malang Regency with the hope that teachers will be able to have more abilities in digital literacy, especially online learning media. The method used in this training is by providing materials, including: Digital Literacy, Powtoon, Kahoot, Google Meet, Zoom, Flashcard, Edmodo, Google Classroom, and Learning Innovation. The materials used are learning modules that have been prepared and printed, PPT, as well as direct practice on a computer and displayed on the LCD. As a result, participants showed positive progress in understanding digital literacy and some of the online learning media that had been provided. Participants have been able to try several application menus provided and the results of the pre-test and post-test have shown positive results. This is very important in order to show the impact of training for online learning in the classroom with the increase in digital literacy skills.
\end{abstract}

Keywords: Pandemic; Online Learning Media; Digital Literacy

\begin{abstract}
Abstrak
Di masa pandemi saat ini, pembelajaran dilakukan secara online, namun banyak guru yang belum mampu memaksimalkan media pembelajaran secara online. Pengabdian ini ditujukan kepada guru SD Negeri di Sumbersekar, Dau, Kabupaten Malang dengan harapan, guru mampu memiliki kemampuan lebih dalam literasi digital khususnya media pembelajaran online. Metode yang digunakan dalam pelatihan ini adalah dengan pemberian materi, antara lain: Literasi digital, Powtoon, Kahoot, Google Meet, Zoom, Flashcard, Edmodo, Google Classroom, dan Inovasi Pembelajaran. Pemberian materi yang digunakan adalah modul pembelajaran yang telah disiapkan dan dicetak, PPT, maupun praktek langsung pada komputer dan ditampilkan pada LCD. Hasilnya, peserta menunjukan kemajuan yang positif dalam memahami literasi digital dan beberapa media pembelajaran secara online yang telah diberikan. Peserta sudah mampu mencoba beberapa menu aplikasi yang diberikan serta hasil pre-test dan post-test telah menunjukkan hasil yang positif. Hal ini sangatlah penting guna menunjukkan dampak pelatihan bagi pembelajaran online di kelas nantinya dengan bertambahnya keterampilan literasi digital.
\end{abstract}

Kata kunci: Pandemi; Media Pembelajaran Online; Literasi Digital 


\section{Pendahuluan}

Di dalam masa pandemi seperti saat ini dan pemberlakuan PPKM di Indonesia, telah banyak membuat pergerakan banyak sektor terganggu. Menurut data yang dipublikasikan oleh CNBC Indonesia (2021), pada tanggal 08 Agustus 2021 pada pukul 12.00 WIB, disebutkan hingga hari tersebut pasien positif berjumlah 3.666.031, pasien sembuh berjumlah 3.084.702, dan meninggal berjumlah 107.096. Dari data tersebut, kasus Covid-19 dalam kurun waktu Sabtu (7/8/2021) pukul 12.00 WIB hingga Minggu (8/8/2021) pukul 12.00 WIB bertambah hingga 26.415

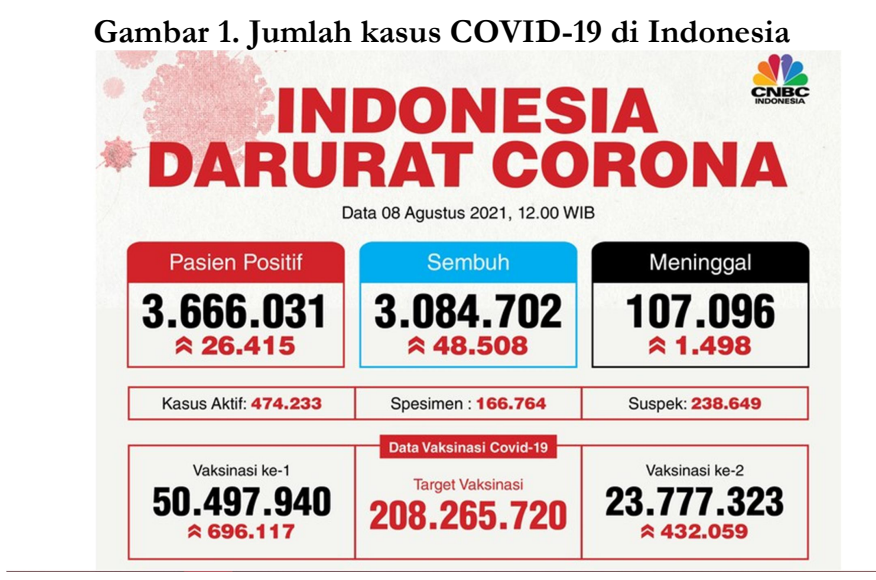

Sumber: CNBC Indonesia

Pandemi COVID-19 memaksa setiap orang untuk dapat bekerja atau melakukan kegiatannya secara daring atau di dalam rumah. Dampak dari pandemi ini terasa di berbagai bidang, tidak terkecuali dengan bidang pendidikan. Menurut data Kementerian Pendidikan dan Kebudayaan Republik Indonesia pada 13 April 2020 saja, terdapat 68.729.037 murid yang belajar di rumah. Dengan jumlah peserta paling banyak yaitu siswa Sekolah Dasar/Madrasah Ibtidaiyah/sederajat. Ada 28.587.688 murid yang melakukan belajar jarak jauh. Sekolah Menengah Pertama/Madrasah Tsanawiyah/sederajat menyusul dengan 13.086.424 murid yang belajar di rumah (Yosepha Pusparisa, 2020).

Gambar 2. Jumlah peserta didik yang belajar di rumah

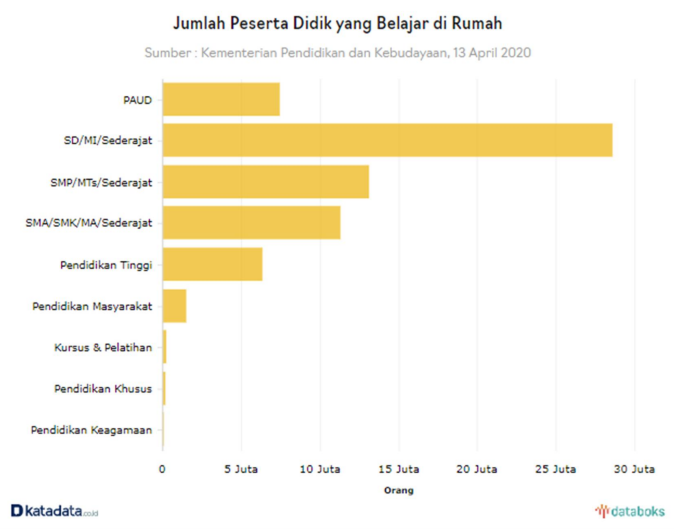

Sumber: Kementerian Pendidikan dan Kebudayaan, 13 April 2020 
Dari data di atas, SD Negeri yang terdapat di Desa Sumbersekar, Kecamatan Dau, Kabupaten Malang juga melakukan kegiatan pembelajaran jarak jauh, yaitu SDN 1 Sumbersekar dan SDN 2 Sumbersekar. Namun, dengan keterbatasan sarana prasarana dan juga kemampuan literasi digital yang ada, banyak dari guru yang belum memanfaatkan berbagai media pembelajaran online dengan semaksimal mungkin. Desa Sumbersekar sendiri merupakan salah satu dari sepuluh desa yang ada di Kecamatan Dau. Desa Sumbersekar memiliki luas wilayah seluas $4.72 \mathrm{Km} 2$ dan terbagi menjadi empat dusun, yaitu dusun Precet, Semanding, Krajan, dan Banjartengah. Terdapat 5 RW dan 26 RT, 2 SD Negeri, 2 SD Swasta, 1 SMP Negeri dan 2 SMP Swasta. Selain itu, terdapat fasilitas publik berupa lapangan bulu tangkis dan sepakbola yang biasa dimanfaatkan oleh masyarakat untuk berolahraga. Total jumlah penduduk warga desa Sumbersekar sebanyak 7.674 dan perekonomian warga didapatkan dari pertanian, peternakan, perkebunan, dan perikanan (Pemerintah Kecamatan Dau, 2017).

Di zaman sekarang, literasi digital sangatlah penting. Literasi digital sendiri merupakan ketertarikan, sikap dan kemampuan individu dalam menggunakan teknologi digital dan alat komunikasi untuk mengakses, mengelola, mengintegrasikan, menganalisis, dan mengevaluasi informasi, membangun pengetahuan baru, serta berkomunikasi dengan orang lain agar dapat berpartisipasi secara efektif dalam masyarakat (Kurniawati \& Baroroh, 2016). Dengan banyaknya pengguna internet di Indonesia seperti saat ini, literasi digital sangat dibutuhkan untuk dapat memanfaatkan dengan maksimal. Menelisik pengumuman APJII pada 9 November 2020, disebutkan bahwa jumlah pengguna internet di Indonesia hingga kuartal II naik menjadi 73,7\% dari populasi atau setara 196,7 juta pengguna. Data ini bahkan hampir menembus 200 juta pengguna dari populasi RI yang 266,9 juta menurut data Badan Pusat Statistik (BPS) (Indonesia Internet Provider Association, 2020). Angka yang sangat banyak, dan hal ini dapat menjadi keuntungan atau kelemahan kita sendiri. Bagaimana cara kita memaksimalkan potensi yang ada pada internet dan meminimalisir dampak negatifnya, yaitu dengan literasi digital itu sendiri.

Menurut penelitian dari Candrasari et al. (2020) yang berjudul "Pengembangan Dan Pendampingan Literasi Digital Untuk Peningkatan Kualitas Remaja Dalam Menggunakan Internet" disebutkan bahwa pemberian literasi digital kepada masyarakat awam mampu membuat masyarakat yang tidak paham sekali dengan aplikasi dan media digital lainnya, akhirnya dapat memahami berbagai aplikasi dan menu-menu yang ada di dalamnya. Hal tersebut menjadi salah satu tujuan awal pengabdian ini yaitu dapat menjadi sumber referensi guru guna mendapatkan pengetahuan dan keterampilan dalam menggunakan media digital khususnya media pembelajaran. Menurut Silvana dan Darmawan (2018) Literasi digital berfungsi sebagai rangkaian gerakan melek media yang dirancang untuk meningkatkan kontrol individu terhadap media yang mereka gunakan, dalam hal ini adalah media pembelajaran secara online. Menurut Harjono (2019), penguasaan literasi digital memungkinkan pembelajar meningkatkan kompetensi kognitif, afektif, dan psikomotor melalui aktivitas belajar yang lebih baik, lebih cepat, lebih mudah, dan menyenangkan di lingkungan belajar digital.

Pengabdian yang dilaksanakan di SD Negeri Sumbersekar 1 ini berfokus dalam memberikan literasi digital khususnya media yang dapat digunakan dalam proses pembelajaran jarak jauh (online). Arti media menurut AECT (Association of Education and Communication Technology) yang 
dikutip oleh Asnawir dan M. Basyiruddin Usman (2002) "media adalah segala bentuk yang dipergunakan untuk proses penyaluran informasi". Sedangkan pengertian lain media adalah alat bantu apa saja yang dapat dijadikan sebagai penyalur pesan guna mencapai tujuan pembelajaran (Djamarah et al., 2006). Jadi, dapat dapat disimpulkan bahwa media adalah segala sesuatu yang dapat digunakan dalam proses transfer informasi guna mencapai tujuan pembelajaran.

Pembelajaran sendiri menurut Hamalik (2003) adalah suatu kombinasi yang tersusun meliputi unsur-unsur manusiawi, material, fasilitas, perlengkapan dan prosedur yang saling mempengaruhi tercapainya tujuan pembelajaran. Sedangkan menurut Departemen Pendidikan dan Kebudayaan (2002) pembelajaran adalah proses, cara, perbuatan yang menjadikan orang atau makhluk hidup belajar. Dapat disimpulkan bahwa pembelajaran adalah segala sesuatu yang dilakukan untuk mendapatkan tujuan dari pembelajaran.

Maka, dapat disimpulkan bahwa media pembelajaran adalah segala bentuk alat untuk penyalur informasi guna mencapai tujuan pembelajaran. Dalam pengabdian ini, media pembelajaran yang akan dibahas adalah media yang bersifat online. Diharapkan dengan adanya pengabdian ini, dapat menambah literasi digital bagi guru yang juga akan berdampak lebih baik pada proses pembelajaran daring serta akan menambah antusiasme murid pada akhirnya.

\section{Permasalahan Mitra}

Berdasarkan hasil observasi dan wawancara yang telah dilakukan. Literasi digital guru SD Negeri di Desa Sumbersekar belum berjalan efektif dan efisien. Penggunaan aplikasi atau media digital lain sebagai penunjang pembelajaran jarak jauh belum dikuasai secara maksimal.

1. Literasi digital untuk pembelajaran jarak jauh belum efektif.

2. Belum mengetahui dengan baik fungsi menu-menu yang ada pada media digital yang digunakan untuk media pembelajaran

3. Sarana dan prasarana yang kurang memadai untuk kegiatan pembelajaran jarak jauh.

4. Belum terbiasanya guru dalam kegiatan pembelajaran jarak jauh.

Melihat permasalah diatas, terciptalah ide untuk melakukan pelatihan literasi digital ini. Melalui literasi digital inilah, bapak/ibu guru SD Negeri di Sumbersekar diharapkan dapat mendorong pengetahuan dan kemampuannya dalam memaksimalkan media pembelajaran jarak jauh. Harapan akhir dari pengabdian ini adalah terciptanya pembelajaran online yang lebih komprehensif dan lebih menyenangkan lagi bagi siswa maupun guru itu sendiri. 


\section{Pedekatan Pelaksanaan Program}

Gambar 3. Alur pengabdian kepada masyarakat

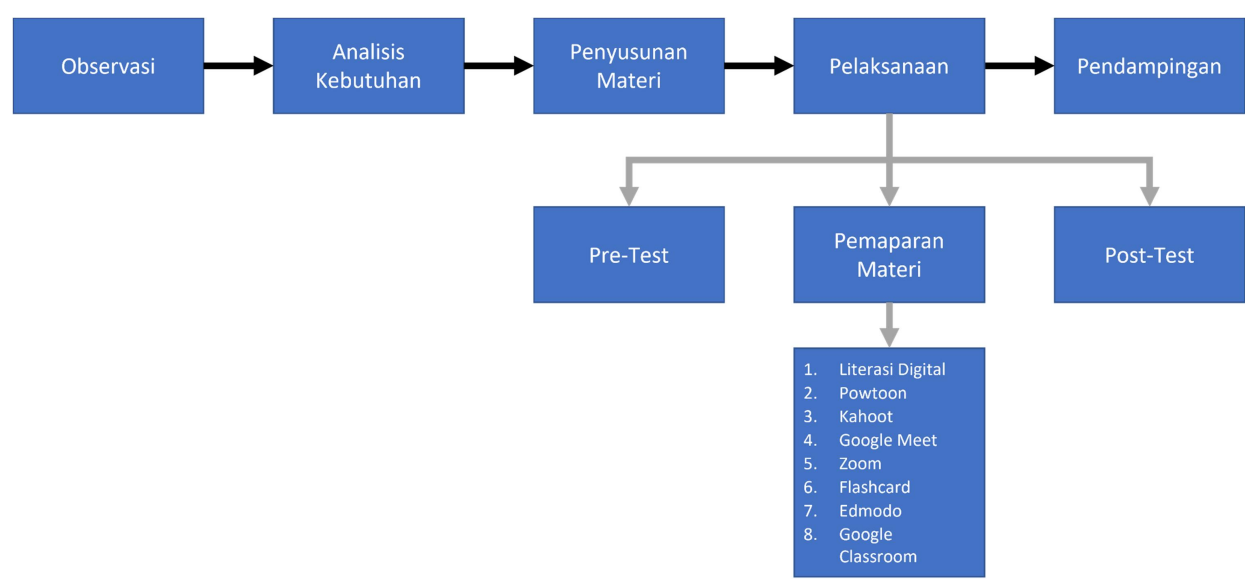

Pelaksanaan pengabdian mahasiswa kepada masyarakat ini telah dilakukan dengan memberikan pelatihan kepada seluruh guru SD Negeri di Sumbersekar, Kecamatan Dau, Kabupaten Malang. SD Negeri yang ada di Sumbersekar adalah SD Negeri Sumbersekar 1 dan SD Negeri Sumbersekar 2. Peserta yang mengikuti kegiatan ini berjumlah 24 orang guru yang berasal dari gabungan SDN Sumbersekar 1 dan SDN Sumbersekar 2 (Kementerian Pendidikan dan Kebudayaan, 2021a, 2021b).

\section{Gambar 4. Peserta Pelatihan}

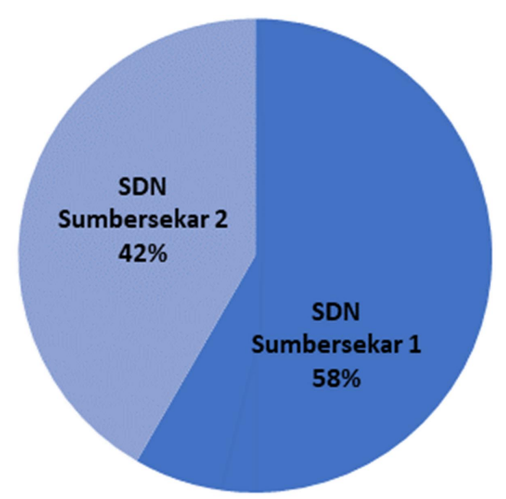

Pelatihan dilaksanakan pada tanggal 25 Agustus 2021 dengan diawali dengan Pemberian PreTest kepada peserta. Setelah itu pemberian materi seperti Literasi digital, Powtoon, Kahoot, Google, Meet, Zoom, Flashcard, Edmodo, Google Classroom, dan yang terakhir berdiskusi mengenai beberapa Inovasi Pembelajaran yang dapat dilakukan di sekolah. Pemberian materi sangat bervariasi, seperti menggunakan modul pembelajaran yang telah disiapkan dan dicetak, menggunakan PPT, maupun praktek secara langsung pada komputer dan ditampilkan pada LCD. Setelah materi berakhir, diadakan diskusi dan tanya jawab mengenai materi yang telah disampaikan dan peserta 
mengisi Post-test yang telah disediakan guna digunakan sebagai alat pengukuran dampak pengabdian ini. Setelah acara selesai, diadakan monitoring hasil pengabdian melalui grup WhatsApp yang bisa dilakukan secara online, dan sebagai wadah untuk saling bertukar pikiran mengenai materi literasi digital.

\section{Pelaksanaan Program}

Pengabdian kepada masyarakat berupa pelatihan literasi digital pembelajaran jarak jauh sangat penting dilakukan di era pandemi saat ini. Kegiatan tersebut memberikan peluang para guru untuk meningkatkan efektifitas pembelajaran kepada siswa. Pelatihan ini menjadi salah satu media berlatih guru untuk meningkatkan kompetensi dalam menggunakan media-media pembelajaran jarak jauh.

\section{Gambar 5. Suasana Pelaksanaan Pelatihan}

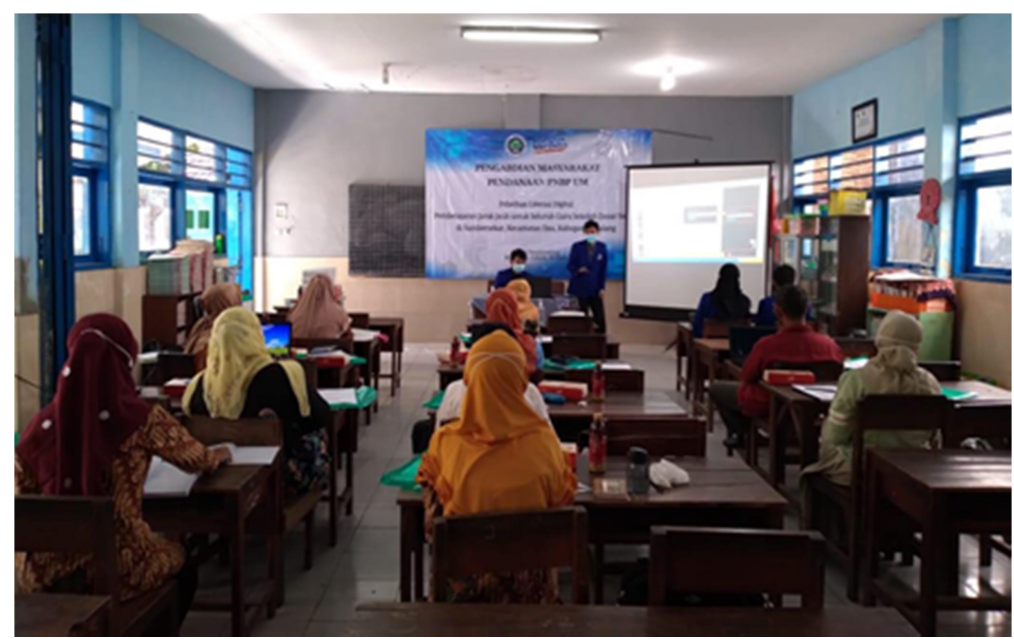

Sebelum melakukan pelatihan, mahasiswa membagikan kuesioner Pre-Test kepada peserta untuk diisi. Kuesioner berisi pertanyaan mengenai pemahaman para guru terhadap materi yang akan disampaikan seputar media yang biasa digunakan dalam pembelajaran jarak jauh. Peserta dapat memilih jawaban dengan pilihan sangat setuju(SS), setuju(S), tidak setuju(TS), dan sangat tidak setuju(STS).

Gambar 6. Pengisian Pre-Test dan Post-Test

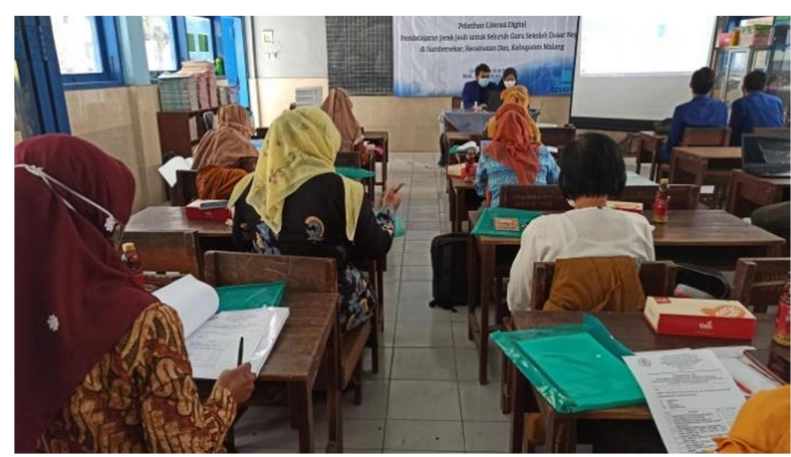




\section{Gambar 7. Kuisioner Pre-Test dan Post-Test}

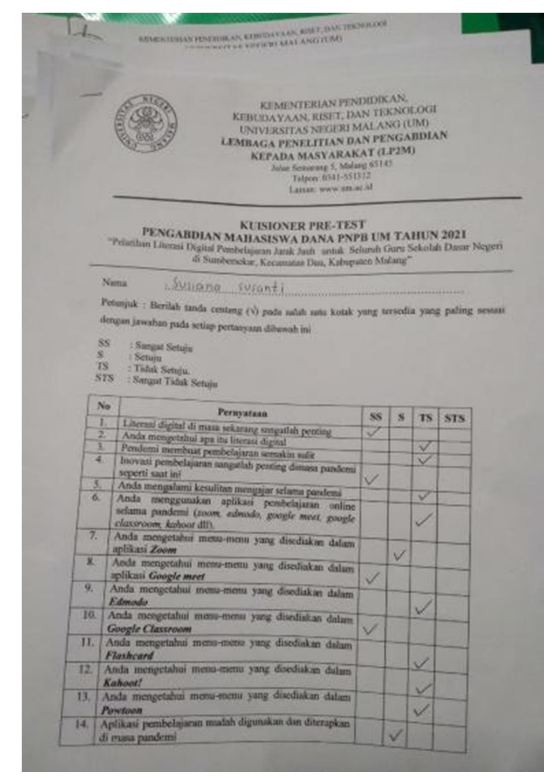

Peserta diberikan modul tercetak, ppt dan pdf yang dapat dipelajari sendiri setelah pelatihan ini selesai. Materi yang dipaparkan dalam pelatihan ini meliputi inovasi pembelajaran, literasi digital, Zoom, Google Meet, Edmodo, Google Classroom, Flashcard, Kahoot, dan Powtoon. Materi Powtoon berisi tentang sejarah dan deskripsi singkat, mengenal menu-menu utama Powtoon, dan cara membuat video Powtoon (Fathoni et al., 2019). Materi Flashcard berisi tentang deskripsi, fitur yang tersedia, hingga cara membuat kartu Flashcard. Materi Edmodo berisi tentang beberapa menu dan fitur yang dapat digunakan untuk mempermudah membuat kuis dan menu-menu lainnya yang dapat membantu mempermudah pekerjaan (Agus \& Shavab, 2020).

\section{Gambar 8. Pemaparan Materi oleh Mahasiswa}

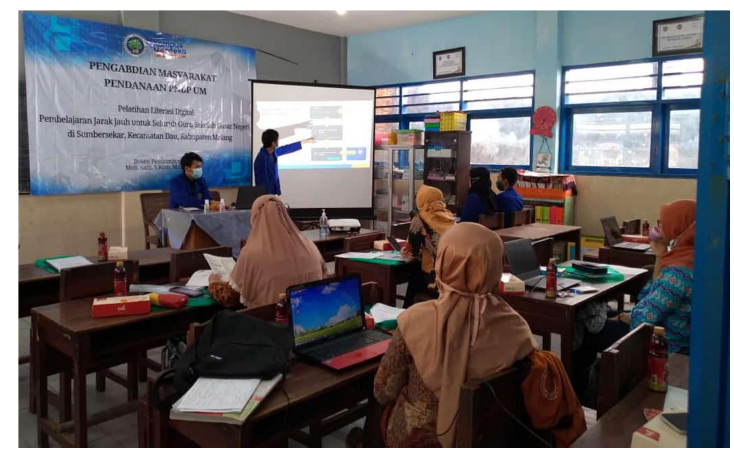

Materi Google Classroom memaparkan deskripsi singkat, cara membuat kelas, cara mengundang siswa, dan cara membuat presensi (Hapsari \& Pamungkas, 2019). Materi Kahoot berisi tentang sejarah singkat, deskripsi, cara membuat akun Kahoot sekaligus melengkapi data pribadi, cara membuat kuis, dan cara import soal kuis dari spreadsheet (Jumila et al., 2018). Dengan mediamedia tersebut diharapkan mampu memaksimalkan dan menambah semangat guru dan siswa-siswi dalam melaksanakan kegiatan belajar mengajar di era pandemi. 
Gambar 9. Peserta Mempraktikkan Materi

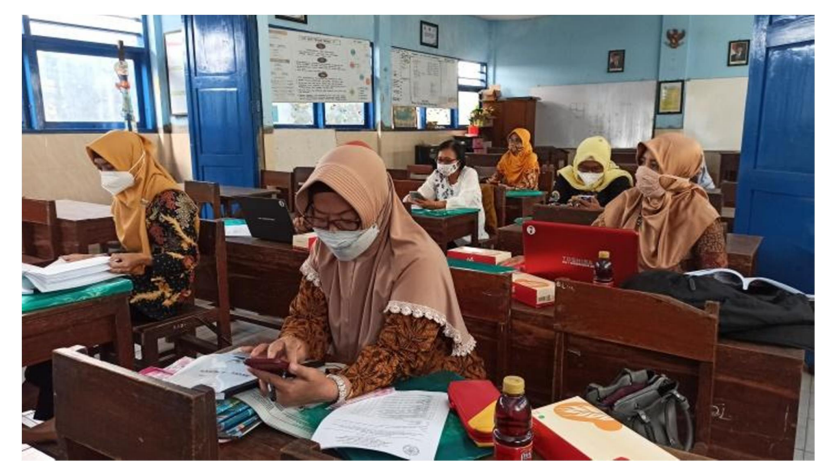

Peserta pelatihan dapat melakukan praktik sesuai dengan materi yang disampaikan. Praktik dilakukan menggunakan laptop atau gawai yang mereka bawa. Untuk mempermudah latihan, peserta dibagikan modul. Sesi tanya jawab disediakan untuk diskusi bagaimana kesulitan yang dihadapi para peserta. Mahasiswa akan membantu memecahkan masalah yang dihadapi peserta dengan cara melakukan pendampingan secara langsung atau pengulangan materi presentasi yang belum dikuasai.

Gambar 10. Sesi tanya jawab dan pendampingan

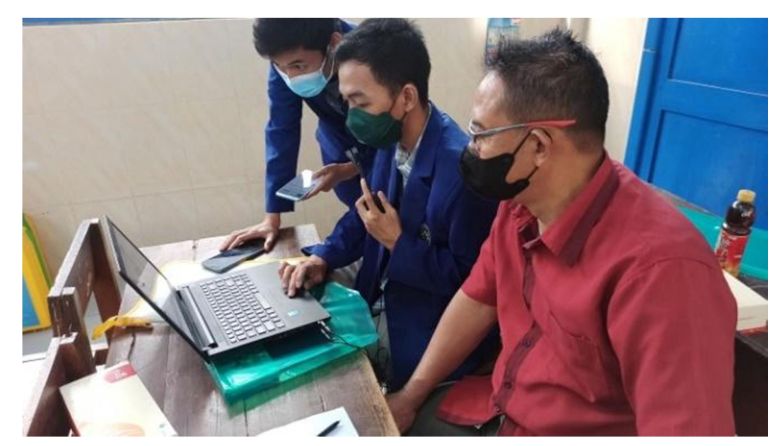

Setelah pelatihan selesai, peserta diberikan kuesioner Post-Test untuk mengukur tingkat keberhasilan pelatihan. Hal ini dimaksudkan untuk mengetahui sejauh mana pemahaman para peserta dan bagaimana dampak pelatihan bagi peserta. Untuk memaksimalkan pelatihan ini, juga telah disediakan sesi tanya jawab, praktik, dan pendampingan. Berikut diagram persentase tingkat pemahaman peserta mengenai materi yang disampaikan pada pelatihan literasi digital pembelajaran jarak jauh. 
Gambar 11. Tingkat Pemahaman Peserta Sebelum dan Sesudah Pelatihan

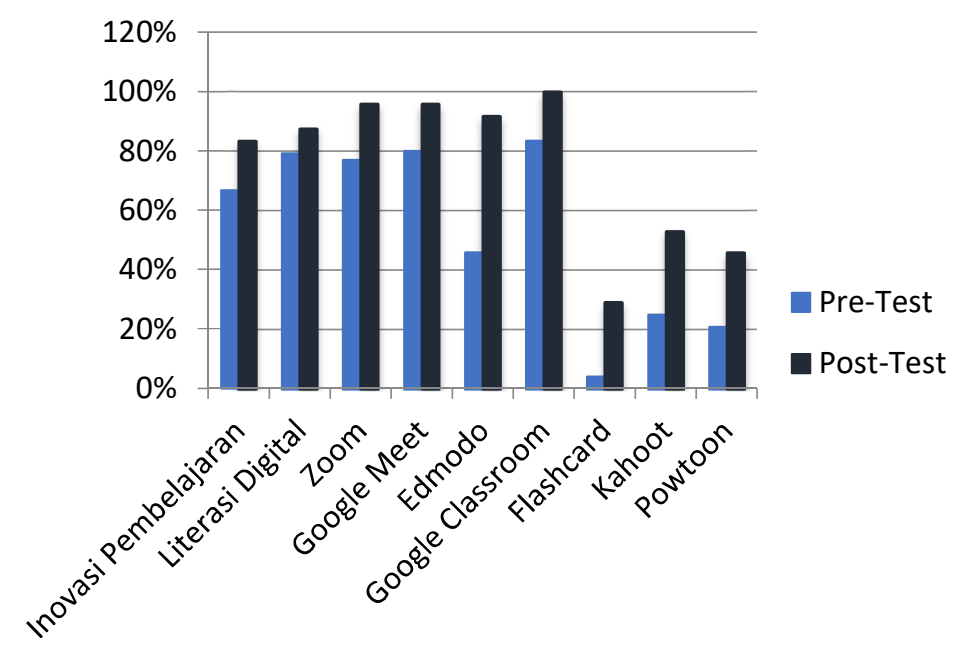

Dari beragam materi yang disampaikan pada saat pelatihan, peserta terbiasa menggunakan google classroom dan google meet. Sedangkan untuk materi yang lain, peserta masih belum bisa menggunakan fitur-fitur yang ada. Persentase peningkatan pemahaman peserta terhadap materi inovasi pembelajaran yaitu sebesar 17\%, materi literasi digital sebesar 8\%, Zoom 19\%, Google Meet 16\%, Edmodo 46\%, Google Classroom 17\%, Flashcard 25\%, Kahoot 28\%, dan Powtoon 25\%.

Tabel 1. Presentase Pemahaman Peserta Sebelum dan Sesudah Pelatihan

\begin{tabular}{|l|l|l|l|l|}
\hline \multirow{2}{*}{$\begin{array}{l}\text { No } \\
\end{array}$} & \multirow{2}{*}{ Materi } & \multicolumn{3}{|l|}{ Persentase Pemahaman } \\
\cline { 3 - 5 } & & Pre-Test & $\begin{array}{l}\text { Post- } \\
\text { Test }\end{array}$ & Peningkatan \\
\hline 1 & Inovasi Pembelajaran & $67 \%$ & $83 \%$ & $17 \%$ \\
\hline 2 & Literasi Digital & $79 \%$ & $88 \%$ & $8 \%$ \\
\hline 3 & Zoom & $77 \%$ & $96 \%$ & $19 \%$ \\
\hline 4 & Google Meet & $80 \%$ & $96 \%$ & $16 \%$ \\
\hline 5 & Edmodo & $46 \%$ & $92 \%$ & $46 \%$ \\
\hline 6 & Google Classroom & $83 \%$ & $100 \%$ & $17 \%$ \\
\hline 7 & Flashcard & $4 \%$ & $29 \%$ & $25 \%$ \\
\hline 8 & Kahoot & $25 \%$ & $53 \%$ & $28 \%$ \\
\hline 9 & Powtoon & $21 \%$ & $45 \%$ & $25 \%$ \\
\hline
\end{tabular}




\begin{tabular}{|l|l|}
\hline Rata-rata & $22 \%$ \\
\hline
\end{tabular}

Hasil menunjukkan bahwa pelatihan memberikan dampak positif bagi peserta. Sebelum pelatihan banyak peserta yang belum memahami media pembelajaran tersebut, khususnya Flashcard, Kahoot, dan Powtoon. Kemudian, setelah pelatihan diselenggarakan terdapat peningkatan pemahaman dengan rata-rata $22 \%$. Peningkatan pemahaman yang terendah pada materi literasi digital yaitu $8 \%$, sedangkan peningkatan pemahaman yang tertinggi yaitu pada materi Edmodo sebesar $46 \%$. Peserta merasa antusias mendapatkan materi dan modul dari pelatihan ini yang dapat dijadikan pedoman dalam latihan mandiri di rumah.

\section{Refleksi Capaian Program}

Kegiatan pengabdian mahasiswa kepada masyarakat yang dilakukan di Sumbersekar, Kecamatan Dau, Kabupaten dengan target guru SD Negeri Sumbersekar 1 dan SD Negeri Sumbersekar 2 telah dilaksanakan. Hasil kegiatan dari pengabdian masyarakat ini telah memberikan dampak yang cukup baik kepada pengetahuan dan pemahaman peserta mengenai literasi digital dan beberapa media pembelajaran secara online. Rata-rata peningkatan pemahaman peserta setelah mengikuti pelatihan yaitu 22\%. Peserta sudah mampu mencoba beberapa menu aplikasi yang diberikan serta hasil pre-test dan post-test telah menunjukkan hasil yang positif juga.

\section{Penutup}

Berdasarkan pemaparan pelaksanaan Kegiatan pengabdian mahasiswa kepada masyarakat di atas, bahwa kegiatan semacam ini telah memberikan dampak yang cukup positif kepada mitra yaitu guru SD di SD Negeri Sumbersekar 1 dan SD Negeri Sumbersekar 2 . Oleh sebab itu, kegiatan ini diharapkan dapat dilaksanakan berkelanjutan pada tahun-tahun berikutnya. Serta perlu dilakukan evaluasi kegiatan agar ke depan dapat menyusun kegiatan pengabdian mahasiswa kepada masyarakat yang lebih baik dan bermanfaat.

Kekurangan pengabdian ini adalah waktu yang masih dirasa kurang dikarenakan dimasa pandemi dan PPKM yang masih berlangsung. Pengabdian ini akan tetap di monitoring melalui group whatsapp untuk dapat bertukar informasi secara online dan sumber referensi bagi inovasi pembelajaran di masa pandemi seperti saat ini secara komprehensif.

\section{Daftar Pustaka}

Agus, O., \& Shavab, K. (2020). Literasi Digital Melalui Pemanfaatan Media Pembelajaran Edmodo Pada Pembelajaran Sejarah. Sejarah Dan Budaya, Vol. 14, N, hlm. 142-152. https://doi.org/10.17977/um020v14i22020p142

Asnawir, \& M. Basyiruddin Usman. (2002). Media Pembelajaran. Ciputat Pers. https://doi.org/979 9668964

Candrasari, Y. C., Dyva Claretta, \& Sumardjiajti. (2020). Pengembangan Dan Pendampingan Literasi Digital Untuk Peningkatan Kualitas Remaja Dalam Menggunakan Internet. Dinamisia: Jurnal Pengabdian Kepada Masyarakat, 4(4), 611-618. https://doi.org/10.31849/dinamisia.v4i4.4003 
CNBC Indonesia. (2021). Jelang PPKM Berakhir, Begini Data Terbaru Covid-19 di RI. CNBC Indonesia. https://www.cnbcindonesia.com/news/20210808173755-16-267031/jelangppkm-berakhir-begini-data-terbaru-covid-19-di-ri

Departemen Pendidikan dan Kebudayaan. (2002). Kamus Besar Bahasa Indonesia. Balai Pustaka.

Djamarah, Bahri, S., \& Zain, A. (2006). Strategi Belajar Mengajar. PT. Rineka Cipta. https://doi.org/979-518-675-2

Fathoni, A., Rosyadi, A., Gunawan, I., Hidayat, M. T., \& Puspasari, A. (2019). Pelatihan Media Presentasi Powtoon dan Sparcol Untuk Guru SD Negeri 9 Purwodadi , Grobogan. Sekolah Tinggi Ilmu Kesehatan Muhammadiyah Gombong, 74-81.

Hamalik, O. (2003). Kurikulum dan Pembelajaran. Bumi Aksara. https://doi.org/9795262327

Hapsari, S. A., \& Pamungkas, H. (2019). Pemanfaatan Google Classroom Sebagai Media Pembelajaran Online Di Universitas Dian Nuswantoro. WACANA: Jurnal Ilmiah Ilmu Komunikasi, 18(2), 225-233. https://doi.org/10.32509/wacana.v18i2.924

Harjono, H. S. (2019). Literasi Digital: Prospek dan Implikasinya dalam Pembelajaran Bahasa. Pena : Jurnal Pendidikan Bahasa Dan Sastra, 8(1), 1-7. https://doi.org/10.22437/pena.v8i1.6706

Indonesia Internet Provider Association. (2020). Internet User Survey 2019-2020. In Asosiasi Penyelenggara Jasa Internet Indonesia (Vol. 74, p. 1). https://apjii.or.id/content/read/104/503/BULETIN-APJII-EDISI-74---November-2020

Jumila, J., Paristiowati, M., Zulhipri, Z., \& Allanas, E. (2018). Analisis Literasi Digital (ICT) Peserta Didik Melalui Pemanfaatan Web Kahoot dalam Pembelajaran Koloid. JRPK: Jurnal Riset Pendidikan Kimia, 8(2), 36-41. https://doi.org/10.21009/jrpk.082.04

Kementerian Pendidikan dan Kebudayaan. (2021a). SD Negeri 1 Sumbersekar. Kementerian Pendidikan Dan Kebudayaan. sekolah.data.kemdikbud: ttp://sekolah.data.kemdikbud.go.id/index.php/chome/profil/807384b6-8c18-e111-8adb$6 \mathrm{~d} 2 \mathrm{c} 70 \mathrm{cfe} 6 \mathrm{ff}$

Kementerian Pendidikan dan Kebudayaan. (2021b). SD Negeri 2 Sumbersekar. Kementerian Pendidikan Dan Kebudayaan. http://sekolah.data.kemdikbud.go.id/index.php/chome/profil/c08d84b6-8c18-e111-9ed0$1774 \mathrm{ad} 5 \mathrm{~d} 3178$

Kurniawati, J., \& Baroroh, S. (2016). Literasi Media Digital Mahasiswa Universitas Muhammadiyah Bengkulu. Jurnal Komunikator, 8(2), 51-66. https://journal.umy.ac.id/index.php/jkm/article/download/2069/2586

Pemerintah Kecamatan Dau. (2017). Profil dan potensi kecamatan dau. Profil Kecamatan Dau.

Silvana, H., \& Darmawan, C. (2018). Pendidikan Literasi Digital Di Kalangan Usia Muda Di Kota Bandung. Pedagogia, 16(2), 146. https://doi.org/10.17509/pdgia.v16i2.11327

Yosepha Pusparisa. (2020). Puluhan Juta Murid Belajar di Rumah. Kementerian Pendidikan dan Kebudayaan. Kementerian Pendidikan Dan Kebudayaan. https://databoks.katadata.co.id/datapublish/2020/05/05/pandemi-covid-19-puluhan-jutasiswa-belajar-di-rumah. 